\title{
Cerebrospinal Fluid Neutrophilic Pleocytosis in Hospitalized West Nile virus Patients
}

\author{
Renee Crichlow, MD, Jessica Bailey, MD, and Cameron Gardner, MD
}

\begin{abstract}
A description of 7 consecutive patients admitted for various forms of neurological impairment. All these patients were found to have cerebrospinal fluid positive for West Nile virus IgM, and routine bacterial cultures were negative. Six of these patients did not present with the typical lymphocytic pleocytosis often quoted when discussing a viral meningitis/encephalitis; rather most presented with a cerebrospinal fluid neutrophilia. (J Am Board Fam Pract 2004;17:470-2.)
\end{abstract}

After the significant increase in West Nile virus (WNV) cases within the Rocky Mountain states ${ }^{1}$ during the summer of 2003, clinicians in the area have grown more familiar with the existence of West Nile virus. ${ }^{2}$ The virus, originally isolated in the West Nile region of Uganda in 1937, appeared for the first time in the United States in New York City during 1999. Its subsequent distribution has been called the "best documented spread of a vector-borne human pathogen in the past century." ${ }^{3}$ In the summer of 2003, human cases of West Nile virus started to appear in significant numbers in the Rocky Mountain States. ${ }^{1}$ Further spread was expected in 2004 as West Nile virus entered the large population centers of the west coast. ${ }^{1}$ This single-stranded RNA virus has a mosquito vector and is amplified in avian hosts. ${ }^{4}$ Both avian and equine hosts experience significant morbidity and mortality ${ }^{5}$ The vast majority of human infections are asymptomatic or exhibit mild febrile symptoms. ${ }^{2}$ Of those persons requiring hospitalization, there is significant morbidity. In severe disease, the greatest predictor for death is advanced age. $^{6-8}$

Most discussions regarding the evaluation and diagnosis of neurological infection, including West Nile virus, regard the presence of lymphocytic pleocytosis in cerebrospinal fluid (CSF), as indicative of viral pathogenesis. ${ }^{3,8-10} \mathrm{We}$ will describe 7 consecutive hospitalized patients presenting with neurological changes in whom the diagnosis of

Submitted, revised, 9 August 2004.

From the Montana Family Medicine Residency Program, Billings. Address correspondence to Renee Crichlow, MD, Montana Family Medicine Residency Program, 123 S. 27th St., Ste. B, Billings, MT 59101 (e-mail: reneec4@u.washington. edu).
West Nile virus was made. Of these, only 1 patient presented with lymphocytic pleocytosis. Most presented with cerebrospinal fluid neutrophilic pleocytosis more generally associated with bacterial infections of the central nervous system (CNS). ${ }^{9}$

\section{Case Reports}

During July and August of 2003, the Montana Family Medicine Residency admitted a total of 7 patients who were eventually diagnosed with West Nile virus central nervous system infection. The information for this report was collected from retrospective chart review. All patients' CSF samples were tested at the Montana State Public Health laboratory, in accordance with the CDC criteria for West Nile virus case determination. This lab used an IgM antibody capture enzyme-linked immunosorbent assay (MAC-ELISA) to detect WNVspecific IgM antibody in CSF. IgM antibody in CSF strongly suggests recent CNS infection, because IgM does not readily cross the blood-brain barrier. IgM in serum may persist longer than 500 days after infection, so a single serum $\operatorname{IgM}$ is not considered diagnostic, in that it may indicate previous remote West Nile virus exposure. ${ }^{11,12}$ In addition, routine bacterial cultures were performed for all patients.

The 7 patients studied ranged in age from 24 to 74 years, with a median age of 55 years. There were 4 men and 3 women in the evaluation. All patients lived in south-central Montana except for 1 from northeast Montana. All patients recalled exposure to mosquitoes.

At presentation to the emergency department, all patients complained of headache. Five had symptoms of fever, chills, nausea, and vomiting. Two patients were brought in with decreased levels 
Table 1. Clinical Features of West Nile Virus Meningoencephalitis $(\mathbf{n}=7)$

\begin{tabular}{lc}
\hline Age, median (range) & $55(24-74)$ \\
Sex & 4 male, 3 female \\
Days since symptoms onset, mean (range) & $3.5(1-7)$ \\
Headache & $100 \%$ \\
Nausea and vomiting & $83 \%$ \\
Photophobia & $66 \%$ \\
Chills & $66 \%$ \\
Malaise & $66 \%$ \\
Fever & $50 \%$ \\
Mental status changes & $33 \%$ \\
\hline
\end{tabular}

of consciousness. One patient reported blurry vision (Table 1). One patient presented twice, the first time with headache, fever, and chills. This patient had an initial negative evaluation, including normal CSF cell count. The patient returned again 3 days later with persistent symptoms and an additional complaint of abdominal pain. At this time, repeat evaluation of this patient's CSF was abnormal and indicative of CNS infection.

CSF samples were taken from all patients, and a cell count was obtained (Table 2). Total cerebrospinal fluid white blood cell counts ranged from 17 to 497 . Five of the patients showed a neutrophilic predominance. In these patients, the average time from onset of symptoms to cerebrospinal fluid sampling was 3.6 days. Only 1 patient showed a lymphocytic predominance; his sample was obtained 2 days after initial onset of his symptoms. One patient's sample showed a monocytosis, with $51 \%$. All the patients' cerebrospinal fluid samples demonstrated elevated protein levels and normal glucose levels.

Table 2. Laboratory Test Results

\begin{tabular}{lcc}
\hline Test & $\begin{array}{c}\text { Range } \\
\text { Median) }\end{array}$ & $\begin{array}{c}\text { Reference } \\
\text { Ranges }\end{array}$ \\
\hline CSF & & \\
Leukocyte count & $17-497(141)$ & $0-5$ \\
Protein & $50-154(73)$ & $15-50$ \\
Glucose & $51-120(62)$ & $50-80$ \\
Differential $\geq 50 \%$ & $6-100 \%(74)$ & All \\
$\quad$ neutrophils (n $=6$ of 7$)$ & & mononuclear \\
cells \\
Blood & Range (Mean) & \\
Leukocyte count & $5.7-19.2(10.5)$ & $4.5-11$ \\
Hyponatremia, serum $<135$ & $122-134(132)$ & $135-145$ \\
$\quad$ mmol/L (n $=6$ of 7$)$ & & \\
\hline
\end{tabular}

In other laboratory data, an elevated serum white cell count with polymorphoneutrophilic predominance was apparent in 3 of the patients. Hyponatremia, which has been noted in many West Nile virus cases ${ }^{5,10,13}$ was present in 4 of our patients (Table 2).

\section{Outcome}

Hospital stays ranged from 3 days to greater than 4 weeks with a median of 7 days of inpatient hospitalization. There were no deaths. One patient required ICU admission with short-term ventilator support. Nonetheless, this patient improved rapidly and was discharged from the hospital within 5 days. Six of those admitted to our service were discharged, improved and stable, but still reporting some malaise and weakness, with very delayed improvement. Three of these patients required skilled nursing facilities for rehabilitation from weakness that impaired independent function. Only 1 patient went home with no significant sequela of the West Nile virus meningoencephalitis.

\section{Literature Review}

A Medline search with MeSH headings "West Nile virus" and "spinal fluid" demonstrated a trend of West Nile virus infections manifesting cerebrospinal fluid cell count with early neutrophilic pleocytosis as an increasingly common finding ${ }^{10,13-16}$

\section{Discussion}

The 2003 outbreak of West Nile virus brought significant increases in the number of human cases reported in the Rocky Mountain States. Although the majority of people infected with West Nile virus will have a mild illness, those that require hospitalization may have significant long-term impairment. ${ }^{3,6,7}$ Compared with the previous year, there was an increase in reported cases of more than 100-fold in Montana and more than 150-fold in Colorado. ${ }^{1}$ As a result of the outbreaks, there has been a greater level of surveillance and vigilance. West Nile virus has become a prominent part of the differential diagnosis for patients presenting with neurological changes.

The cellular content of the cerebrospinal fluid has long been used as an indicator regarding diagnoses and treatment decisions in CNS infections. Our experiences during the summer of $2003 \mathrm{dem}$ onstrated that the occurrence or absence of a lym- 
phocytic pleocytosis is not predictive regarding pathogenesis in the presence of West Nile virus CNS infections. Although it is unusual that cerebrospinal fluid cell counts were typical of viral infection in only one of these patients, ${ }^{3,4,8,10,17}$ other investigators have also noted the possibility of neutrophilic predominance of cerebrospinal fluid pleocytosis in subsets of patients during prior outbreaks of West Nile virus infections. ${ }^{7,10}$

It has been postulated that this neutrophilic predominance may be more evident earlier in the course of the infection. ${ }^{10}$ Our overall average from symptom onset to CSF sampling was 3.5 days. The cerebrospinal fluid finding of neutrophilic pleocytosis may be the result of earlier presentation to care by patients and increased vigilance by the medical community during a highly publicized outbreak of West Nile virus. With this in mind, it would seem most prudent for the evaluation of a patient presenting with neurological changes to consist of the full battery of cerebrospinal fluid laboratory tests, including West Nile virus CSF IgM, regardless of the initial cerebrospinal fluid white cell differential.

\section{References}

1. CDC: West Nile virus-Surveillance and control case count of West Nile virus disease 2003 [monograph on the Internet]. Atlanta (GA): Centers for Disease Control and Prevention; 2003 [cited 2003 Sep 11]. Available from: http://www.cdc.gov/ncidod/ $\mathrm{dvbid/westnile/surv \& controlCaseCount03.htm.}$

2. CDC fact sheet: West Nile virus (WNV) infection: information for clinicians [monograph on the Internet]. Atlanta (GA): Centers for Disease Control and Prevention; 2003 [cited 2003 Sep 10]. Available from: http://www.cdc.gov/ncidod/dvbid/westnile/ resources/fact_sheet_clinician.htm.

3. Petersen LR, Marfin AA. West Nile virus: a primer for the clinician. Ann Intern Med 2002;137:173-9.

4. Nash D, Mostashari F, Fine A, et al, for the 1999 West Nile Outbreak Response Working Group. The outbreak of West Nile virus infection in the New York City area in 1999. N Engl J Med 2001; 344:1807-14.
5. Wamsley HL, Alleman AR, Porter MB, Long MT. Findings in cerebrospinal fluids of horses infected with West Nile virus: 30 cases (2001). J Am Vet Med Assoc 2002;221:1303-5.

6. Chowers MY, Lang R, Nassar F, et al. Clinical characteristics of the West Nile fever outbreak, Israel, 2000. Emerg Infect Dis 2001;7:675-8.

7. Weiss D, Carr D, Kellachan J, et al, for the West Nile virus Outbreak Response Working Group. Clinical findings of West Nile virus infection in hospitalized patients, New York and New Jersey, 2000. Emerg Infect Dis 2001;7:654-8.

8. Petersen LR, Marfin AA, Gubler DJ. West Nile virus. JAMA 2003;290:524-8.

9. Beers $M H$, Berkow R, Bogin RM, et al, editors. Trauma of the head [monograph on the Internet]. In: The Merck manual of diagnosis and therapy. Whitehouse Station (NJ): Merck and Co.; 2004 [cited 2003 Nov 23]. Available from: http://www.merck.com/ mrkshared/mmanual/section14/chapter175/175a.jsp

10. Pepperell C, Rau N, Krajden S, et al. West Nile virus infection in 2002: morbidity and mortality among patients admitted to hospital in south central Ontario. CMAJ 2003;168:1399-405.

11. Roehrig JT, Nash D, Maldin B, et al. Persistence of virus-reactive serum immunoglobulin $\mathrm{m}$ antibody in confirmed West Nile virus encephalitis cases. Emerg Infect Dis 2003;9:376-9.

12. Prince HE, Hogrefe WR. Detection of West Nile virus (WNV)-specific immunoglobulin $m$ in a reference laboratory setting during the $2002 \mathrm{WNV}$ season in the United States. Clin Diagn Lab Immunol 2003;10:764-8.

13. Jeha LE, Sila CA, Lederman RJ, Prayson RA, Isada $\mathrm{CM}$, Gordon SM. West Nile virus infection: a new acute paralytic illness. Neurology. July 8, 2003 2003; 61:55-9.

14. John TJ. Spinal cord disease in West Nile virus infection [letter]. N Engl J Med 2003;348:564-6.

15. Li J, Loeb JA, Shy ME, et al. Asymmetric flaccid paralysis: a neuromuscular presentation of West Nile virus infection. Ann Neurol 2003;53:703-10.

16. Robinson RL, Shahida S, Madan N, Rao S, Khardori $\mathrm{N}$. Transient parkinsonism in West Nile virus encephalitis. Am J Med 2003;115:252-3.

17. Sejvar JJ, Haddad MB, Tierney BC, et al. Neurologic manifestations and outcome of West Nile virus infection. JAMA 2003;290:511-5. 